\title{
MITOLOGI BUYUT CILI \\ Kepercayaan dan Habituasi Transendental Suku Using, Banyuwangi
}

\author{
Jainudin \\ UIN Sunan Ampel Surabaya \\ Email: jainudin1962@yahoo.com
}

\begin{abstract}
The history of the mythology of Using Tribe in Banyuwangi has been rooted within the ancestral beliefs of Hinduism and Buddhism. Using Tribe used to do a pilgrimage (ziarah) to what so called Petilasan Buyut Cili which is believed as ground-breaker of the construction of Using. This research aims to describe history of Petilasan Buyut Cili, cultural changes of the ancestral faith, and transcendental habituation. Using phenomenological approach, this research attempts to elucidate that social belief could create a basically well-balanced connection between human and God. This research found that (1) the growth of the belief of Using Tribe has been influenced by Department of Tourism which established Kemiren Village as a traditional and cultural village; (2) urbanization changes religious patterns of Using Tribe; and (3) the tribe has been transformed to be a religiousbased tourist destination. The tribe practiced annual religious rites which are conserved simultaneously to become a transcendental habituation for the people of Desa Kemiren.
\end{abstract}

[Sejarah lahirnya mitologi Suku Using berakar pada kepercayaan nenek moyang mereka yang beragama Hindu-Buddha. Masyarakat Using memiliki budaya berziarah pada sebuah petilasan bernama Buyut Cili, tokoh mitologi yang dipercayai sebagai orang yang berjasa pada konstruksi masyarakat Using. Tulisan ini memaparkan sejarah petilasan Buyut Cili, menjelaskan adanya perubahan kepercayaan nenek moyang, dan habitus transendental di dalam Suku Using. Menggunakan pendekatan fenomenologi melalui 
wawancara mendalam, observasi dan dokumentasi, penelitian ini ingin menjelaskan bahwa kepercayaan masyarakat merupakan elemen dasar terciptanya hubungan antara manusia dengan Tuhan. Masyarakat Using menggunakan nilai-nilai kepercayaan tersebut dalam bentuk aktivitas upacara mistis. Hasil dari penelitian ini menunjukkan bahwa (1) perkembangan kepercayaan suku Using dipengaruhi oleh keputusan dinas pariwisata yang menjadikan Desa Kemiren sebagai desa adat; (2) kehadiran warga pendatang berpengaruh pada pola keagamaan yang ada di Desa Kemiren; (3) Suku Using menjadi objek wisata religi bagi mereka yang ingin mengetahui secara langsung bentuk lama dari sebuah kepercayaan nenek moyang. Suku Using memiliki beberapa upacara keagamaan dan adat istiadat sudah dilaksanakan secara turun temurun. Masyarakat setempat memiliki kesadaran yang kuat untuk terus melestarikan budaya kepercayaan tersebut dan dalam perkembangannya budaya yang semula hanya mitos berubah menjadi perilaku keagamaan bagi masyarakat Desa Kemiren.]

Keywords: mythology, local culture, traditional belief, transcendental babituation.

\section{Pendahuluan}

Indonesia adalah salah satu negara kepulauan dengan jumlah penduduk yang hampir mencapai 280 juta jiwa. ${ }^{1}$ Negara ini memiliki aneka ragam budaya dan adat istiadat yang dirawat dan dijaga secara turun temurun oleh masyarakatnya. Adat istiadat inilah yang kemudian tumbuh dan membentuk peradaban dan kebudayaan Nusantara.

Salah satu suku yang menarik untuk diteliti dan dikaji adalah Suku Using, suku yang juga disebut sebagai "Wong Blambangan”. Suku ini merupakan penduduk mayoritas di beberapa kecamatan di Banyuwangi serta dianggap sebagai sub suku Jawa. ${ }^{2}$ Ada banyak adat istiadat dan budaya masyarakat suku Using yang menarik untuk diteliti, termasuk pola keagamaan dan sikap mistik masyarakat setempat. Menarik, karena kepercayaan adalah kemauan seseorang untuk bertumpu pada entitas atau

\footnotetext{
${ }^{1}$ Lihat Aris Ananta dkk., Demography of Indonesia's Ethnicity (Singapore: ISEAS Publishing, 2015).

${ }^{2}$ Kementerian Dalam Negeri, Badan Pusat Statistik (Jakarta, 2010), 234.
} 
zat lain dimana seseorang menaruh keyakinan terhadapnya. Kepercayaan merupakan kondisi jiwa dan mental yang didasarkan oleh situasi seseorang dan konteks sosialnya. Ketika seseorang mengambil suatu keputusan, ia akan lebih memilih keputusan berdasarkan pilihan dari orang- orang yang lebih dapat ia percaya daripada yang kurang dipercayai. ${ }^{3}$

Kepercayaan adalah wilayah pembahasan kajian psikologis yang merupakan perhatian untuk menerima apa adanya berdasarkan harapan dan tujuan terhadap perilaku yang baik dari orang lain. Kepercayaan konsumen didefinisikan sebagai kesediaan satu pihak untuk menerima risiko dari tindakan pihak lain berdasarkan harapan bahwa pihak lain akan melakukan tindakan penting untuk pihak yang mempercayainya, terlepas dari kemampuan untuk mengawasi dan mengendalikan tindakan pihak yang dipercaya. ${ }^{4}$

Kajian ini menggunakan konsepsi habitus ${ }^{5}$ yang dirumuskan dari sebuah sistem disposisi-disposisi (skema-skema persepsi, pikiran dan tindakan yang diperoleh dan bertahan lama). Agen-agen individual mengembangkan disposisi-disposisi ini sebagai tanggapan terhadap kondisi-kondisi objektif yang dihadapinya. Bourdieu menteorikan ini pada penanaman struktur sosial objektif kedalam pengalaman mental dan subjektif dari si agen. ${ }^{6}$ Struktur sosial objektif diserap ke dalam perangkatperangkat personal disposisi-disposisi kognitif dan somatik, sedangkan struktur subjektif tindakan agen kemudian disetarakan dengan struktur objektif dan urgen yang masih ada di ranah sosial tersebut. Maka muncullah hubungan yang bersifat doxic (doxa adalah semacam bymne atau pujian). Doxa adalah kepercayaan dan nilai-nilai tak sadar, berakar mendalam, mendasar, yang dipelajari (learned) dan dianggap sebagai universal, terbukti dengan sendirinya (self-evident) yang menginformasikan tindakan dan pikiran seorang agen dalam ranah tertentu (fields). Doxa

\footnotetext{
${ }^{3}$ Christine Moorman, Rohit Deshpande, dan Gerald Zaltman, "Factors Affecting Trust in Market Research Relationships," Journal of Marketing. Vol 57. pp 81-10, (1993), 375.

${ }^{4}$ Roger C. Mayer, et al., "An Integrative Model of Organizational Trust," The Academy of Management Review, Vol. 20, No. 3 (July, 1995), 709-734.

${ }^{5}$ Laurence Goldstein, The Philosopher's Habitat: An Introduction to Investigations in, and Applications of Modern Philosophy (New York: Routledge, 1990), 46.

${ }^{6}$ Pierre Bourdieu, The Field of Cultural Production: Essays on Art and Literature (Cambridge: Polity, 1993), 322.
} 
cenderung mendukung pengaturan sosial tertentu pada ranah tersebut, mengistimewakan pihak dominan dan menganggap posisi dominan tersebut sebagai sesuatu yang terbukti dengan sendirinya serta lebih disukai secara universal (universally favorable).

Kategori-kategori tentang pemahaman dan persepsi yang membentuk habitus selaras dengan organisasi objektif dari ranah yang bersangkutan. Bourdieu melihat habitus sebagai kunci reproduksi sosial yang bersifat sentral dalam membangkitkan dan mengatur praktik-praktik yang membentuk kehidupan sosial. Individu-individu belajar untuk mendambakan hal-hal yang dimungkinkan bagi mereka dan tidak mengaspirasi hal-hal yang tidak tersedia bagi mereka. Kondisi dimana individu hidup membangkitkan disposisi-disposisi yang cocok dengan kondisi tersebut, termasuk selera pada seni, sastra, makanan, dan musik. Kondisi terlihat tunduk pada tatanan tertentu, sementara tatanan membuat agen-agen condong untuk mengerjakan sesuatu sesuka hati, menolak apa yang dikategorikan tertolak dan menghendaki hal-hal yang memang tak terhindarkan.

Physical space and social space have a lot of things in common. Just as physical space is defined by the mutual externality of parts, social space is defined by the mutual exclusion (or distinction) of positions which constitute $i t$, that is, as a structure of juxtaposition of social positions. Social agents, but also things as they are appropriated by agents and thus constituted as properties, are situated in a location in social space which can be characterized by its position relative to other locations (as standing above, below or in between them) and by the distance which separates them. ${ }^{7}$

Bourdieu menambahkan tentang ruang fisik dan ruang sosial dalam memberikan makna tentang habitus. Menurutnya, habitus adalah struktur yang terstruktur untuk menstrukturisasi sebuah struktur. ${ }^{8}$ Suku Using, dengan semua budaya yang dimilikinya, membentuk struktur untuk menstrukturisasi struktur yang ada. Pada hakikatnya, habituasi ini lahir dari pembiasaan melalui karakter yang terus menerus dilakukan sehingga ruang fisik sudah diinternalisasikan dengan sendirinya.

\footnotetext{
7 Pierre Bourdieu, Physical Space, Social Space and Habitus (Oslo: Department of Sociology, University of Oslo, 1995), 10.

${ }^{8}$ Ibid., 15.
} 
Beberapa teori di atas bisa digunakan untuk melihat dan menganalisis sisi-sisi psikologi kepercayaan dan keyakinan masyarakat Using pada Makam Buyut Cili. Bagi mereka, petilasan Buyut Cili mempunyai kekuatan magis dan dianggap keramat. Dari sisi sosiologi, penelitian ini berupaya mencari gambaran bagaimana sebenarnya kepercayaan masyarakat Suku Using terhadap petilasan Buyut Cili, dengan cara mengeksplorasi kepercayaan masyarakat terhadap nilai-nilai religius dan habituasi transendental suku Using terhadap makam Buyut Cili.

Penelitian ini dilakukan di Desa Kemiren, Glagah, Banyuwangi. Objek penelitiannya adalah seluruh masyarakat Desa Kemiren dan pihakpihak yang dijadikan sebagai sampel penelitian. Penelitian ini sangat memperhatikan karakteristik dan keragaman objek penelitian, mulai dari populasi hingga teknik sampling. Lebih dari itu, data penelitian ditopang dengan sumber data sekunder berupa dokumen-dokumen tertulis seperti buku teks dan lainnya. Metode pengumpulan data dikelompokkan ke dalam dua cara: interaktif dan non-interaktif. Metode interaktif meliputi interview dan observasi berperan-serta, sedangkan metode non-interaktif meliputi observasi tak berperan-serta, tehnik kuesioner, dan pencatatan dokumen. ${ }^{9}$

\section{Suku Using dan Mitologi Buyut Cili}

Masyarakat Using dalam kehidupan sehari-hari dikenal memegang teguh nilai-nilai filosofis dari adat istiadat mereka sebagai identitas dan menjaga kesadaran untuk mempertahankan budaya dan jati diri. Beberapa ahli mendefinisikan masyarakat sebagai sekumpulan anggota individu yang berkumpul untuk bekerja sama guna mencapai tujuan bersama. Sebut saja misalnya R. M. MacIver dan Charles H. Page yang menyatakan bahwa Masyarakat ialah suatu sistem dari kebiasaan atau adat istiadat dan tata cara, dari wewenang dan kerjasama antara berbagai kelompok dari beberapa individu dan golongan. Pengawasan tingkah laku serta kebiasaan dengan kebebasan-kebebasan manusia dalam masyarakat merupakan jalinan hubungan sosial sebab masyarakat selalu mengalami perubahan-

9 H.B. Sutopo, Metodologi Penelitian Kualitatif : Dasar teori dan Terapannya dalam Penelitian,(Surakarta: Universitas Sebelas Maret, 2006), 23. 
perubahan yang dinamis. ${ }^{10}$ Sementara Ralph Linton berpendapat bahwa masyarakat merupakan setiap kelompok manusia yang telah hidup dan bekerja bersama cukup lama, sehingga mereka dapat mengatur diri mereka dan menganggap diri mereka sebagai suatu kesatuan sosial, dengan batasbatas yang dirumuskan dengan jelas dengan norma dan aturan yang telah disepakati oleh anggota masyarakatnya. ${ }^{11}$ Selo Soemardjan mendefinisikan masyarakat sebagai orang-orang yang hidup bersama dan menghasilkan kebudayaan serta peradaban. ${ }^{12}$

Dari pengertian-pengertian tentang masyarakat di atas dapat disimpulkan bahwa masyarakat adalah sekelompok manusia yang saling berinteraksi, yang memiliki prasarana untuk berkegiatan, dan ada keterikatan untuk mencapai tujuan bersama. Maka dalam hal ini dapat dijelaskan bahwa masyarakat Using menguatkan pribadinya dengan kepercayaan dan dalam kehidupannya mereka melakukan habituasi transendental untuk mencapai tujuan bersama.

Bagi masyarakat Using, kepercayaan diyakini sebagai kemauan seseorang untuk bertumpu atas orang, zat atau entitas lain. Kepercayaan merupakan kondisi mental yang didasarkan oleh situasi seseorang dan konteks sosialnya. Ketika seseorang mengambil suatu keputusan, ia akan lebih memilih keputusan berdasarkan pilihan dari orang- orang yang lebih dapat ia percaya daripada pilihan orang yang kurang ia percaya. ${ }^{13}$ Kepercayaan dan keyakinan adalah wilayah psikologis, gejala jiwa untuk menerima apa adanya objek keyakinan dan kepercayaan berdasarkan harapan terhadap perilaku yang baik dari orang lain. Johnson dan Johnson berpendapat bahwa kepercayaan (trust) adalah adanya keyakinan dan kepercayaan bahwa anggota lain akan memberikan keuntungan dan terbentuk melalui sikap terbuka, menerima, mendukung, berbagi, dan kerja sama di antara individu-individu yang menjadi anggota dalam kelompok. ${ }^{14}$

\footnotetext{
${ }^{10}$ Baca R. M. MacIver dan Charles H. Page, Society: An Introductory Analisys (New York: MacMillan, 1962).

${ }^{11}$ Baca Ralph Linton, The Cultural Background of Personality (New York: D. AppletonCentury Co, 1945).

12 Soerjono Soekanto, Sosiologi Suatu Pengantar (Jakarta: Rineka Cipta, 2009) 212-213.

${ }^{13}$ Christine Moorman, "Factors Affecting Trust in Market..." 305.

${ }^{14}$ David W Johnson and Roger D Johnson, Learning Together and Alone: Cooperative, Competitive, and Individualistic Learning (Boston: Allyn and Bacon, 1991), 78.
} 
Ada beberapa aspek kepercayaan yang mampu menghadirkan kesatuan dalam masyarakat. Pertama adalah keterbukaan (opennes) yang meliputi kesediaan individu untuk berbagi informsi, ide, pemikiran, perasaan, pendapat, dan reaksi terhadap hal yang sedang dialami. Kedua, kemauan berbagi (sharing). Berbagi berarti kesediaan individu untuk membagikan kemampuan dan sumber daya yang dimilikinya kepada orang lain guna membantu pencapaian tujuan bersama. Ketiga, penerimaan (acceptance) yang berarti melakukan komunikasi dengan orang lain dan menghargai pendapat orang lain tersebut tentang sesuatu hal yang sedang dibicarakan. Keempat, dukungan (support) yang meliputi komunikasi antarindividu sehingga orang lain mengenal kelebihannya dan percaya bahwa orang lain tersebut mampu mengatur secara produktif situasi di mana mereka berada.

Keinginan dan kehendak bekerjasama (cooperative intention) meliputi harapan individu untuk bisa bersikap kooperatif dan keyakinan bahwa orang lain juga akan bersikap kooperatif untuk mencapai tujuan bersama. Sutrisno mengatakan bahwa mayoritas penduduk Desa Kemiren, yang notabene adalah suku Using, masih memegang teguh adat istiadat dan budaya yang ada. Masyarakat Using adalah masyarakat terbuka atau egaliter dan mudah berkomunikasi dengan orang lain. Kata Sutrisno, "Kami selaku kepala adat suku Using memperlakukan semua anggota masyarakat setara, namun tetap memakai etika dan sopan santun. Kita senantiasa hormat menghormati antar anggota masyarakat Using. Orang Using cukup ramah dalam menyambut setiap tamu yang berkunjung ke Desa Kemiren.”

Profesor Leckerkerker, ${ }^{15}$ peneliti Belanda menulis bahwa Suku Using yang berdiam di desa Kemiren, Glagah, Banyuwangi ini merupakan laskar Majapahit yang menyingkir dari desa ketika masih tinggal di wilayah Majapahit tatkala mendapati kerajaannya mulai runtuh pada tahun $1478 \mathrm{M}$. Dengan kekalahan itu, masyarakat dan laskar Majapahit melakukan eksodus ke berbagai arah, akibat tekanan kerajaan Demak. Sebagian dari mereka yang melakukan eksodus akhirnya menetap di Gunung Bromo (sebagai suku Tengger), menetap di Pulau Bali (sebagai suku Bali) dan sebagian lagi menetap di Blambangan (sebagai suku Using). Wilayah

${ }^{15}$ Lekkerkerker, C. "Het voorspel der vestiging van de Nederlandsch macht op Bali and Lombok" dalam Bijdragen tot de Taal, Land-en Volkenkunde van Ned (Indië, 1989), 79. 
terakhir ini meliputi beberapa desa seperti desa Kemiren, Olehsari, dan Mangir. Namun dalam literatur Belanda, Pegeaud ${ }^{16}$ mengatakan bahwa suku Using adalah penduduk asli Banyuwangi, sisa laskar kerajaan Blambangan yang menyingkir akibat perang Puputan Bayu (1771-1772 M) melawan kolonial Belanda di bawah pimpinan Raden Mas Rempeg atau Pangeran Jagapati. Sama seperti desa-desa adat yang ada di penjuru Nusantara, Desa Kemiren-yang menjadi pusat kebudayaan Warga Using-memiliki beragam mitos dan makna filosofis yang menyertainya. Keberadaan Barong Using atau juga biasa disebut Barong Kemiren yang menjadi kesenian khas kampung itu juga tak lepas dari kepercayaan turun temurun dari warga desa Kemiren terhadap kesenian yang ada di dalam masyarakat. Hal ini adalah salah satu model dalam meningkatkan keyakinan dan kepercayaan warga masyarakat dalam pengembangan budaya.

Aekanu Hariyono saat memandu peneliti berkunjung ke Desa Adat Kemiren menuturkan, konon ada seorang begawan bernama Mbah Buyut Cili merantau mencari lokasi menetap yang memiliki tanah subur serta ditumbuhi tiga serangkai pohon kemiri, duren merah dan aren (Kemiren). Dari istilah ini lahirnya nama yang diabadikan sebagai nama desa Kemiren.

\begin{abstract}
"Dari Mbah Buyut Cili inilah muncul nama Kemiren dan melekat menjadi nama desa hingga sekarang. Selain Petilasan Mbah Buyut Cili juga ada petilasan yang lain yang ada di desa ini, yaitu petilasan Mbah Buyut Sapuah. Bersama dengan Mbah Sapuah, Buyut Cili lantas tinggal dan menetap serta mendirikan sebuah padepokan dan perkampungan baru untuk ditempati sebagai wilayah untuk rumah tinggal dan mengembangkan ajaran yang telah beliau yakini dari sejak dulu secara turun temurun dalam menjalani hidup beragama."
\end{abstract}

\footnotetext{
16 Pigeaud, Dr. Th. G. Th., Literature of Java Catalogue Raisonné of Javanese Manuscripts (Leiden: The Library of The University of Leiden). Lihat juga The Netherlands Volume I Synopsis of Javanese Literature 900-1900 AD (The Hague: Martinus Nijhoff, 1967), 102.

17 Wawancara dengan Bapak Aekanu Hariyanto sebagai Kasi Wisata dan Budaya, Dinas Kebudayaan. Dia menjelaskan bahwa masyarakat Desa Kemiren dalam perkembangan keyakinan dan kepercayaannya sudah mulai proses Islamisasi Budaya dengan mengubah pola pengembangan budaya melalui doktrin agama, bahkan Islamisasi budaya Desa Kemiren, Glagah, Banyuwangi.
} 
Keberadaan dua tokoh yang memiliki pengetahuan tentang pola tanam serta dianggap sakti ini lantas menjadikan Perkampungan Kemiren ramai didatangi warga Suku Using. Singkat cerita, Buyut Cili tiba-tiba muksa atau hilang dan muncullah pagebluk yang disebabkan munculnya wabah penyakit. Saat muksa itu, Buyut Cili sempat mengirimkan pesan ke Mbah Sapuah untuk membuat ruwat desa dengan barong saat hari raya. Sejak saat itu, Ruwat Barong yang disebut sebagai Ritual Idher Bumi mengusir segala bencana rutin digelar di Desa Kemiren khususnya di hari kedua Hari Raya Idul Fitri. "Awalnya Barong Using ini untuk ritual mengusir wabah penyakit dan pagebluk," kata Aekanu Hariyanto. Ritual Idher Bumi tak hanya dengan ruwat barong, melainkan juga dilengkapi dengan ritual tumpeng sewn yang menyajikan makanan khas tanah Using, yakni pecel pitik (ayam). Makanan dari ayam kampung yang sudah dipanggang, dan diberi bumbu parutan kelapa pedas.

Masyarakat Using percaya bahwa Mbah Buyut Cili ${ }^{18}$ adalah orang sakti Majapahit yang beragama Hindu. Dalam mitosnya, beliau sesungguhnya adalah pelarian dari kerajaan Macan Putih, sambungan Kerajaan Blambangan dan Majapahit. Hal ini sesuai namanya "Cili" yang dalam bahasa Using berarti "pelarian". Konon, Buyut Cili adalah pendeta HinduBuddha. Beliau bersama sang istri terpaksa melarikan diri dari kerajaan Macan Putih, sebab sang raja yang bengis itu juga seorang kanibal. Sang raja hendak merebut sang istri untuk dimakan. Karena Buyut Cili tidak bermaksud menentang, beliau memilih menyingkirkan diri sampai akhirnya tiba di desa Kemiren.

Versi lain mengisahkan bahwa Buyut Cili menyingkir ke desa Kemiren akibat tekanan kerajaan Demak. Konon, Barong yang dipercaya sebagai binatang mistis menjadi peliharaan Buyut Cili. Tak jauh dari jalan utama desa, petilasan Buyut Cili ada di area kebun. Sampai sekarang petilasan

\footnotetext{
18 Andrew Beatty mendefinisikan Buyut Cili sebagai roh penguasa (roh alus) desa yang dipercayai oleh masyarakat sekitar, seperti seekor macan jadi-jadian. Ia menggambarkan dalam buku Variasi Agama di Jawa bahwa menurut kepercayaan orang lama Buyut Cili kadang-kadang muncul sebagai seekor anjing, akan tetapi yang paling sering adalah macan putih dengan sorot mata bagai suluh yang mengerikan. Sosok penolong yang menjaga desa, berkeliling ke tempat-tempat sepi yang terkadang seseorang hanya bisa melihat kilatan cahaya mata. Meski digambarkan seperti macan yang menakutkan, Buyut Cili dipercaya melakukan aktivitas seperti makan nasi saat prosesi selamatan meski tak seorang pun bisa melihatnya.
} 
Buyut Cili masih dikeramatkan dan didatangi pengunjung, terutama malam Jumat dan Minggu sore. Mereka biasanya mengadakan selamatan tumpeng pecel pitik urap kelapa. Petilasan Buyut Cili memiliki unsur religi dan magis yang begitu kental. Buyut Cili sendiri diambil dari kosakata Using "Ngili" yg berarti "mengungsi". Mbah Buyut Cili memiliki empat orang anak, yakni Mas Anggring, Mas Buronto, Siti Ambari \& Siti Sundari. Dari empat orang inilah secara turun temurun lahir asal muasal suku Using sampai saat ini, dan menempati wilayah Kemiren.

Dalam membangun kepercayaan keagamaan, masyarakat Kemiren memegang teguh perjalanan historisitas agama. Mereka sepertinya meyakini fenomena keberagamaan manusia melewati pintu masuk antropologi budaya dan menganggapnya sebagai dimensi lain dari applied sciences. ${ }^{19}$ Hal ini bisa dilihat dari awal mula keyakinan masyarakat Using meyakini terhadap makam Buyut Cili sebagai makam keramat dan dikeramatkan, yang sering dikunjungi masyarakat untuk berdoa.

Fenomena di atas merupakan cermin perilaku keagamaan yang dilakukan berdasar ajaran turun temurun dari nenek moyang. Masyarakat Using sangat menjunjung tinggi nilai-nilai leluhur dan melestarikannya. Bagi mereka, menjadi Bagian dari suku Using adalah sebuah kebanggaan tersendiri. Semakin banyak orang yang mengenal suku Using, mereka semakin merasa bahwa eksistensi mereka diakui. Hal ini mereka wujudkan dengan cara mengembangkan berbagai kebudayaan sebagai upaya mengembangkan sikap religiositas masyarakat yang diaplikasikan dalam kehidupan sehari-hari. ${ }^{20} \mathrm{Hal}$;ain yang menarik dari masyarakat Using adalah penerimaan mereka terhadap kehadiran orang lain untuk mengetahui keseharian dan budaya mereka, terutama bagaimana mereka menghormati leluhur.

\section{Ritual Adat dan Habituasi Transendental Suku Using}

Habitus merupakan istilah yang hadir dari tradisi pemikiran filsafat. Dalam bahasa latin habitus diartikan sebagai kebiasaan (babitual) dan penampilan diri (appearance). Konsep ini menunjukkan aspek perlengkapan

19 M. Amin Abdullah, Studi Agama Normativitas dan Historisitas (Yogyakarta: Pustaka Pelajar, 2011), 26.

${ }^{20}$ Jalaluddin, Psikologi Agama (Jakarta: PT. RajaGrafindo Perkasa, 2012), 32. 
bagi substansi tertentu seperti yang ditemukan dalam pemikiran Aristoteles mengani pembagian ada (being). ${ }^{21}$ Dalam hal ini, habitus bisa menjadi fenomena kolektif seperti yang dikatakan oleh Bourdieu bahwa habitus sebagai akal sehat (common sense) yang merefleksikan pembagian objektif dalam struktur kelas, memungkinkan setiap orang untuk memahami dunia sosial, namun tidak menancapkan dirinya secara seragam. Dikaitkan dengan fungsi habitus dalam membentuk strukturstruktur yang ada dalam masyarakat, habitus sebagai hasil keterampilan yang menjadi tindakan praktis (tidak selalu disadari) yang kemudian diterjemahkan menjadi suatu kemampuan yang kelihatannya alamiah dan berkembang dalam lingkungan sosial tertentu.

Habitus transendental dalam kajian ini merupakan habitus yang didefinisikan sebagai struktur mental atau kognitif ${ }^{22}$ yang digunakan aktor untuk menghadapi kehidupan sosial. Habitus yang diartikan sebagai struktur sosial yang diinternalisasikan yang diwujudkan sebagai contoh bagaimana seseorang mau melakukan serangkaikan kegiatan dalam ritual budaya sehingga menjadi kebiasaan dan dia merasa bahwa dia sudah internalisasikan tindakan kultural tersebut dalam dirinya. Dapat dikatakan bahwa secara psikologis habitus ini masuk pada internalisasi dari struktur sosial yang menjadi suatu kebiasaan yang terus diwujudkan untuk kepentingan bersama.

Ada beberapa ritual adat yang dilakukan oleh suku Using. Antara lain upacara Kupatan, upacara ritual Barong Idher Bumi (sebagai tolak pagebluk. atau tolak balak), upacara Tumpeng Sewu (sebagai tanda rasa syukur atas hasil bumi yang melimpah dengan membuat sedekah), upacara Rebo Wekasan (upacara selamatan air), upacara Penampan, upacara sedekah bumi (sebagai wujud rasa syukur masyarakat), upacara Adeg-Adeg Tandur, Mecuti Pari (mencambuk padi ketika mulai berbuah), selamatan sapi (selamatan usai membajak sawah), upacara Kebonan, selamatan jenang sumsum, selamatan Syuroan, dan selamatan Nduduk Lemah.

Bagi masyarakat desa Kemiren, semua upacara dan selamatan tersebut adalah sebuah bentuk perubahan dan perkembangan menuju

\footnotetext{
${ }^{21}$ Bagus Takwin, "Habitus: Perlengkapan dan Kerangka Panduangn Gaya Hidup," dalam Resistensi Gaya Hidup: Teori dan Realitas (Yogayakarta: Jalasutra, 2006), 35-54.

22 Richard Jenkins, Pierre Bourdeu (London: Routlegde, 1992), 17.
} 
perilaku masyarakat lebih baik. Semua dilakukan sebagai bentuk amalan dan perbuatan yang dilakukan berdasar tuntunan agama yang dianut oleh masyarakat setempat dengan berbagai variasi dan toleransi Agama. Kegiatan masyarakat dengan berbagai produk budaya merupakan suatu hal yang positif sebagai wujud dinamika dari masyarakat. Dari sisi seni budaya, masyarakat Kemiren juga mempunyai Tari Gandrung, Tari Kuntulan, Tari Barong, Gedhogan, Mocoan Lontar Yusuf, Burdah, Jaran Kencak, Kiling, Angklung Pajak, Angklung Caruk, Angklung Tetek, Kenthulitan, Seni Ukir, arsitektur Rumah Adat Using, batik Gajah Uling dan lain-lain. ${ }^{23}$

Beberapa Ritual Adat yang memiliki pengaruh besar pada pola habituasi transendental bagi suku Using adalah sebagai berikut.

Pertama, Barong Idher Bumi. Masyarakat desa Kemiren memiliki habituasi budaya yang unik dan terasa magis, seperti memiliki hubungan transendental dalam pelaksanaannya. Acara ini selalu dilaksanakan pada hari kedua Idul Fitri atau tanggal 2 Syawal Hijriyah. Tradisi ini dalam masyarakat suku Jawa dimaknai kurang lebih sebagai upacara bersih desa, yang juga dilaksanakan setiap tahun menurut hari jadi desanya masingmasing. Upacara Barong Idher Bumi dan upacara Bersih Desa sama-sama dimaknai sebagai ucapan syukur atas hasil panen yang berlimpah serta keselamatan masyarakat desa selama tahun yang silam. Selain itu juga memohon berkah keselamatan untuk tahun mendatang.

Sesuai aturan bakunya, acara ritual Barong Idher Bum ${ }^{24}$ ini harus tepat dimulai pada pukul 2 siang. Pemilihan waktu ini memiliki arti filosofis yang diyakini suku Using secara turun-temurun. Menurut mereka, angka 2 adalah angka yang disuka oleh Tuhan Yang Maha Kuasa. Angka 2 menyiratkan berbagai hal dan anasir kehidupan. Sebagai contoh, Tuhan menciptakan laki-laki dan perempuan, menciptakan siang dan malam, menciptakan benar dan salah, menciptakan suka dan duka dan banyak lagi yang sifatnya berpasang-pasangan. Bagi lare (orang) Using, mereka dilarang memulai acara di luar jam 2 siang, karena apabila pantangan itu dilanggar diyakini akibatnya akan mendatangkan petaka bagi masyarakat dan desanya. Ritual Barong Idher Bumi dibuka dengan tarian Gandrung anakanak kemudian dilanjutkan tari Jaranan Bhuto khas Blambangan. Jaranan

\footnotetext{
${ }^{23}$ Wawancara dengan Adi, Kemiren Banyuwangi, 13 Oktober 2019.

${ }^{24}$ Wawancara dengan Purwadi, Kemiren, 13 Oktober 2019.
} 
Bhuto ini ditampilkan berdelapan orang. Dengan dandanan serupa raksasa, wajah bertaring tampak garang namun tetap artistik. Rambut menjuntai panjang sebahu ditutup mahkota warna emas. Usai acara Jaranan Bhuto, grup Barong mulai di-idher-kan (diarak) ke sepanjang jalanan desa sejauh 3 kilometer, dengan diiringi musik yang meriah, berirama rancak. Arakarakan Barong ini dilantuni bacaan mocopatan dan bakaran dupa oleh para sesepuh dan diikuti masyarakat umum dengan suka cita. Berjalan paling depan dalam ritual Barong Idher Bumi adalah sesepuh desa yang bertugas Sembur Othik-othik (melempar sesaji berupa beras kuning dicampur bunga dan uang koin recehan) sejumlah 99.900.

Alasan memilih bilangan tersebut karena Allah ditafsirkan suka pada angka ganjil, dan angka 99 merujuk pada Asmaul Husna, nama-nama Allah yang Maha Suci. Upacara Sembur Othik-othik ini ditujukan kepada masyarakat penonton yang berada di sepanjang kiri kanan jalan. Ritual yang disebut Lukiran oleh masyarakat Using ini dimaksudkan sebagai "sembur rejeki" dan berkah keselamatan bagi masyarakat. Usai Barong Idher Bumi dinyatakan selesai, maka sampailah pada puncak acara yakni selamatan bersama masyarakat sepanjang jalan desa dengan sajian Tumpeng Pecel Pitik, yaitu nasi putih yang gurih dengan urap ayam bakar bumbu kelapa. Menurut Sutrisno acara Barong Idher Bumi ini selalu diadakan setiap tahun pada hari kedua Idul Fitri. Tradisi ini wajib dilaksanakan sebagai rasa syukur atas hasil panen dan keselamatan selama setahun yang lewat.

Tradisi Barong Idher Bumi adalah tradisi yang sudah dilaksanakan secara turun-temurun sejak ratusan tahun lalu. Biasanya semua proses ritual ini sudah selesai dilakukan sebelum bedug Magrib. Dalam ritual ini diketahui bahwa keberadaan Barong Kemiren tak bisa dilepaskan dengan keberadaan Mbah Buyut Cili, sebuah ritual yang menjadi representasi kepercayaan masyarakat bahwa salah satu elemen dasar terciptanya hubungan baik antara manusia dengan tuhannya adalah adanya interaksi yang intens di antara keduanya, plus interaksi antara warga dengan warga lain untuk mencapai tujuan bersama. Untuk melestarikan nilai dan adatistiadat tersebut, pemerintah Kabupaten Banyuwangi menggelar festival dan acara kesenian seperti Festival Ngopi Sepuluh Ewu hingga Festival Tumpeng Sewu setiap tahunnya di Kemiren. 
Secara visual Barong Kemiren memiliki tampilan spesifik dengan warna merah, hijau, kuning, putih dan hitam. Warna-warna ini menyimpan arti dan simbolisasi khusus. Barong Kemiren memiliki wujud unik. Ia memiliki sayap berjumlah empat dengan mahkota dan jamang di bagian kepalanya. Kesan sepintas yang muncul adanya pengaruh budaya Islam semisal Buroq, kuda berkepala manusia dan bersayap yang menjadi tunggangan rasulullah dalam peristiwa isra mikraj. Hal ini merupakan simbolisasi agama yang dianut masyarakat Desa Kemiren, symbol Buroq. ${ }^{25}$ Jamang bundar besar warna merah mengesankan gada "besi kuning" pusaka Minak Jingga, Raja Blambangan dalam kisah pertunjukkan Ketoprak, Prabuloro dan Janger Blambangan (Banyuwangi). Tafsir ini muncul setelah mempelajari sifat atau karakter masyarakat Using dengan ciri budaya Using yang sinkretis, yakni dapat menerima dan menyerap budaya masyarakat lain untuk diproduksi kembali menjadi budaya Using. ${ }^{26}$

Meski sangat lekat dengan mitos, namun cerita Barong Using sebenarnya punya banyak makna hidup yang hingga kini terus dipegang turun temurun warga sekitar. Mitologi bermunculan di balik adat dan tradisi yang dilestarikan itu. Pertanyaan semacam "kenapa Barong Using banyak mengandung unsur segitiga?" seringkali muncul. Salah satu penjelasannya adalah: segitiga merupakan simbol hubungan antara warga Using dengan tuhan, sesama manusia, dan alam semesta. Masyarakat Using secara prinsipil senantiasa menjaga hubungan dengan alam. Mereka, misalnya, tidak akan pernah dan pantang menimbun atau menutup akar pepohonan. "Akar pohon yang keluar ke atas tanah dilarang dipotong ataupun ditimbun, tapi manusialah yang harus beradaptasi dengan mencari jalan lain sehingga tidak sampai menginjak akar pohon yang keluar dan tidak tertutup tanah," jelas Aekanu. Selain itu, segitiga mengarah ke atas juga sebagai simbol bahwa segala sesuatu harus mengarah pada tuhan sebagai wujud sifat selalu menyembah kepada Sang Pencipta alam.

Selain bentuk ritual, Barong Using juga menjadi sarana warga sekitar untuk melakukan perlawanan dengan Belanda. Melalui kesenian ini, warga sering berkumpul untuk membicarakan strategi melawan Belanda. Jika

\footnotetext{
${ }^{25}$ Bryan S. Turner, Relasi Agama dan Teori Sosial Kontemporer (Yogyakarta: IRCISoD, 2012), 132.

${ }^{26}$ Heru SP Saputra, Memuja Mantra (Yogyakarta: LKIS, 2007), 23.
} 
dulu Barong Kemiren hanya dimainkan tiap hari raya, kini Banyuwangi menjadikannya sebagai sebuah tradisi baru untuk menarik minat wisatawan. Hal inilah yang menjadikan Desa Kemiren sebagai desa pengembangan destinasi wisata sekaligus menjadi media pengembangan sumber pendapatan bagi Banyuwangi. Yanuarta Bramuda, Kepala Dinas Kebudayaan dan Pariwisata Banyuwangi menjelaskan bahwa sejak dua tahun lalu, pemerintah daerah terus mempromosikan kesenian ini untuk menarik wisatawan berkunjung ke Desa Kemiren sehingga kini Barong Kemiren bisa dinikmati tidak hanya setahun sekali tapi bisa dimainkan setiap saat. $^{27}$

Kedua, Sedekah Bumi. Ritual ini merupakan upacara adat yang melambangkan rasa syukur manusia terhadap Tuhan Yang Maha Esa yang telah memberikan rezeki melalui bumi. Upacara ini sangat populer di Indonesia, khususnya di Pulau Jawa. Upacara ini sama dengan upacara Penampan Sedekah Laut yang dilakukan setahun sekali oleh masyarakat pesisir, khususnya nelayan. Upacara Penampan dilaksanakan sebagai rasa syukur atas hasil yang diperoleh nelayan dari menangkap ikan di laut. Biasanya, Sedekah Bumi dilaksanakan pada hari kedua Idul Fitri, tanggal 2 Syawal Hijriyah.

Tradisi Sedekah Bumi ${ }^{28}$ dalam masyarakat suku Jawa dimaknai kurang lebih sebagai upacara Bersih Desa, yang juga dilaksanakan setiap tahun menurut hari jadi desanya masing-masing. Upacara ini dimaknai sebagai ucapan syukur atas hasil panen yang berlimpah serta keselamatan masyarakat desa. Proses melestarikan budaya yang telah dilakukan tersebut menghasilkan nilai yang berbeda pada karakter masyarakat Kemiren. Hal tersebut karena proses habituasi yang telah dilakukan terus menerus dijalankan dan oleh masyarakat Kemiren digunakan sebagai falsafah dalam kehidupan sehari-hari.

Ketiga, upacara Tumpeng Sewu. Upacara ini biasa dilakukan oleh Masyarakat Desa Kemiren seharian penuh. Mereka menggelar tradisi

\footnotetext{
${ }^{27}$ Wawancara dengan M. Yanuarta Bramuda, Kepala Dinas Pariwisata dan Kebudayaan Kabupaten Banyuwangi.

${ }^{28}$ Herliyan Bara Wati, "Pengaruh dan Nilai-Nilai Pendidikan Upacara Sedekah Bumi Terhadap Masyarakat," Jurnal Program Studi Pendidikan Babasa dan Sastra Jawa UMP. Vol.2 No. 4, (2013).
} 
Tumpeng Sewu sebagai wujud syukur atas hasil panen yang berlimpah dan sebagai ritual tolak bala. Biasanya, upacara ini dimulai tepat pukul 08.00 pagi hingga pukul 15.00 WIB. Warga berlomba-lomba menjemur kasur tidur tepat di depan rumah yang disebut Mepe Kasur. Pada pukul 15.30 WIB, setelah salat Ashar, dilakukanlah penampilan Barong menelusuri jalanan desa dengan iring-iringan penari dan alat musik tradisional. Para warga melihat pertunjukan tersebut, Bersama para tokoh dan sesepuh desa yang membaur bersama warga. Dalam acara ini warga memanfaatkan waktu untuk silaturahmi dengan tetangga sebagai wujud guyub rukun dan gotong-royong. ${ }^{29}$

Keempat, Rebo Wekasan. Upacara yang juga dikenal dengan sebutan Rebo Pungkasan ini diadakan setahun sekali, pada hari Selasa (malam Rabu) di minggu terakhir bulan Sapar Hijriyah. Kata Sapar identik dengan kata Shafar, yakni bulan kedua dalam kalender Hijriyah. Upacara adat ini berpuncak pada hari Selasa malam atau malam Rabu. Upacara ini dipusatkan di depan masjid dan seminggu sebelum puncak acara diadakan keramaian berupa pasar malam. Upacara ini dipilih hari Rabu, karena konon pada hari terakhir dalam bulan Sapar tersebut adalah hari di mana Allah menurunkan bala. Berdasarkan penjelasan dari nenek moyang, pada hari itulah kemudian masyarakat mengadakan upacara dan menyebutnya dengan istilah Rebo Wekasan atau Rebo Pungkasan.

Upacara Rebo Wekasan ini diselenggarakan sebagai ungkapan rasa syukur kepada Yang Maha Agung, serta menghormati bulan Sapar, dengan harapan Tuhan akan memberikan kesembuhan dari segala penyakit, memberikan berkah untuk kesuksesan usaha dan tujuan-tujuan tertentu. Upacara Rebo Wekasan memiliki beberapa versi mitos, namun makna dan prosesi upacara tersebut ada kesamaan, yakni upacara untuk tolak balak. Masyarakat Desa Kemiren meyakini bahwa dengan mengadakan kegiatan Rebo Wekasan yang diisi dengan doa bersama dan sedekah akan menjauhkan masyarakat dari bala dan musibah. ${ }^{30}$ Proses transformasi nilai-

\footnotetext{
29 Wawancara dengan Bapak Sukri, sesepuh dan tokoh masyarakat Desa Kemiren, Glagah, Banyuwangi. Ia menyampaikan bahwa setiap acara kebudayaan atau adat adalah hiburan bagi warga dan memiliki nuansa keagamaan.

30 Wawancara dengan Modin Desa Kemiren. Dulu, masyarakat berkumpul di Sendang atau Punden desa sebagai tempat berkumpul untuk doa bersama dengan mengujubkan tumpeng yang sudah disediakan oleh masyarakat. Dalam perkembangannya, acara Rebo
} 
nilai kehidupan dalam masyarakat Using bertumbuh kembang dalam kepribadian yang religius melalui habituasi budaya. Seperti yang dijelaskan oleh Fakri Gaffar, ${ }^{31}$ ada tiga ide penting dalam menjelaskan pendidikan karakter: transformasi nilai, kepribadian, dan perilaku.

Bentuk lain yang bisa ditemukan dari habituasi transendetal suku Using ialah dari ritual $A d e g-A d e g$ Tandur, yaitu upacara persiapan untuk tanam padi bagi masyarakat desa Kemiren yang meliputi ritual Mecuti Pari (mencambuk saat padi mulai berisi), selamatan Pari (saat padi mulai dipanen), dan Selamatan Sapi (dilakukan usai waktu membajak). Meski terlihat sangat kultural, namun kepercayaan pada tuhan diaplikasikan dalam setiap ritual. Dari proses awal yang dimulai dari menyebutkan nama tuhan hingga pada penutupan ritual dengan doa agar tuhan memberkati alam dan memberikan hasil alam yang melimpah. Habituasi ini terus dilakukan dari generasi ke generasi. Mereka senantiasa memiliki kesadaran untuk menjaga nilai-nilai kearifan lokal.

Salah satu ritual yang dirawat dan dilestarikan dalam setiap tahun adalah ritual "sungkem" ke makam Buyut Cili, sosok yang dipercaya sebagai sesepuh yang babat desa Kemiren. Suku Using memiliki ritual tersendiri yang dikhususkan untuk mengeramatkan sosok mitologis Buyut Cili, yakni Ritual Kenduri di makam Buyut Cili. Ritual ini digelar tiap malam Senin dan malam Jumat. Punden sesepuh desa ini berada di sebuah gubuk anyaman bambu di Alas Kemiren. Gelar Kenduri di pusara Buyut Cili dilakukan sesuai tata cara Islam di tanah Jawa, yaitu tradisi kirim doa meminta berkah dan keselamatan pada Tuhan Yang Maha Esa. Hal ini dimaksudkan untuk menghindari perbuatan syirik atau menyekutukan Allah. Meski begitu, syiar tradisi dan adat istiadat kuno di depan pusara sang tokoh tetap khusuk dan sakral. Usai ritual kirim doa yang dipimpin juru kunci sekaligus generasi Barong Kemiren, acara berlanjut dengan menyantap tumpeng khas orang Blambangan.

\footnotetext{
Wekasan dilaksanakan di tempat ibadah semisal masjid dan musala. Kemudian dilaksanakan doa bersama dengan ber-tawasul kepada Nabi, para wali dan ulama. Lalu disusul dengan bersedekah untuk tolak balak.

31 Fakri Gaffar, Pendidikan Karakter Berbasis Islam (Yogyakarta: Makalah Workshop Pendidikan Karakter Berbasis Agama), 22.
} 
Ada tiga jenis menu tumpeng yang biasa disajikan di acara kenduri ini. Menu pertama, pecelpitek (ayam), yaitu ayam kampung yang dipanggang kemudian dibumbui parutan kelapa dan sambal. Kemudian ada sego golong, nasi dibungkus daun pisang. Lauk pauknya, telur rebus dicampur bumbu pecel seperti pecel pitek. Sego golong dimaksudkan agar yang punya hajat pikirannya bisa plong (bebas atau lega).

\section{Penutup}

Kepercayaan atau keyakinan masyarakat adalah salah satu elemen dasar terciptanya hubungan baik antara manusia dengan tuhannya. Nilai kepercayaan dan keyakinan seperti itu dapat diwujudkan dalam bentuk aktivitas upacara mistis yang dilakukan oleh masyarakat untuk mewujudkan sikap keagamaan dan perilaku budaya. Ada beberapa upacara yang dilakukan oleh masyarakat Using dalam rangka membangun media saling berinteraksi dan memiliki keterikatan untuk mencapai tujuan bersama. Misalnya melalui sikap terbuka, menerima, mendukung, berbagi, dan kerjasama di antara anggota masyarakat. Kepercayaan dan keyakinan tersebut dibingkai dan dilaksanakan secara turun temurun atas kesadaran masyarakat setempat. Dalam perkembangannya, budaya yang semula hanya dianggap sebagai mitos menjelma menjadi perilaku keagamaan melalui proses habituasi transendental dalam tubuh masyarakat desa Kemiren, Glagah, Banyuwangi.

\section{Daftar Pustaka}

Abdullah, M. Amin. Studi Agama Normativitas dan Historisitas. Yogyakarta: Pustaka Pelajar, 2011.

Adlin, Alfithri. Resistensi Gaya Hidup: Teori dan Realitas. Yogayakarta: Jalasutra, 2006.

Ananta, Aris dkk. Demography of Indonesia's Ethnicity. Singapore: ISEAS Publishing, 2015.

Bourdieu, Pierre. Physical Space, Social Space and Habitus. Oslo: Department of Sociology, University of Oslo, 1995. 
Bourdieu, Pierre. The Field of Cultural Production: Essays on Art and Literature. Cambridge: Polity, 1993.

Gaffar, Fakri. Pendidikan Karakter Berbasis Islam. Yogyakarta: Makalah Workshop Pendidikan Karakter Berbasis Agama.

Goldstein, Laurence. The Philosopher's Habitat: An Introduction to Investigations in, and Applications of Modern Philosophy. New York: Routledge, 1990. Jalaluddin. Psikologi Agama. Jakarta: PT. RajaGrafindo Perkasa, 2012. Jenkins, Richard. Pierre Bourdeu. London: Routlegde, 1992.

Johnson, David W and Johnson, Roger D. Learning Together and Alone: Cooperative, Competitive, and Individualistic Learning. Boston: Allyn and Bacon, 1991.

Kementerian Dalam Negeri. Badan Pusat Statistik. Jakarta, 2010.

Lekkerkerker, C. "Het voorspel der vestiging van de Nederlandsch macht op Bali and Lombok" dalam Bijdragen tot de Taal, Land-en Volkenkunde van Ned. Indië, 1989.

Linton, Ralph. The Cultural Background of Personality. New York: D. Appleton-Century Co, 1945.

MacIver, R. M. dan Page, Charles H. Society: An Introductory Analisys. New York: MacMillan, 1962.

Mayer, Roger C. et al. "An Integrative Model of Organizational Trust." The Academy of Management Review, Vol. 20, No. 3. 1995.

Moorman, Christine et al. "Factors Affecting Trust in Market Research Relationships," Journal of Marketing. Vol 57. 1993.

Pigeaud, Dr. Th. G. Th. Literature of Java Catalogue Raisonné of Javanese Manuscripts . Leiden: The Library of The University of Leiden.

Saputra, Heru SP. Memuja Mantra. Yogyakarta: LKIS, 2007.

Soekanto, Soerjono. Sosiologi Suatu Pengantar. Jakarta: Rineka Cipta, 2009.

Sugiyono. Metode Penelitian Pendidikan: Pendekatan Kuantitatif, Kualitatif Dan R \&D. Bandung: Alfabeta, 2014.

Sutopo, HB. Metodologi Penelitian Kualitatif: Dasar teori dan Terapannya dalam Penelitian. Surakarta: Universitas Sebelas Maret, 2006.

Turner, Bryan S. Relasi Agama dan Teori Sosial Kontemporer. Yogyakarta: IRCISoD, 2012. 
Wati, Herliyan Bara. "Pengaruh dan Nilai-Nilai Pendidikan Upacara Sedekah Bumi Terhadap Masyarakat." Jurnal Program Studi Pendidikan Bahasa dan Sastra Jawa UMP. Vol.2 No. 4, (2013). 